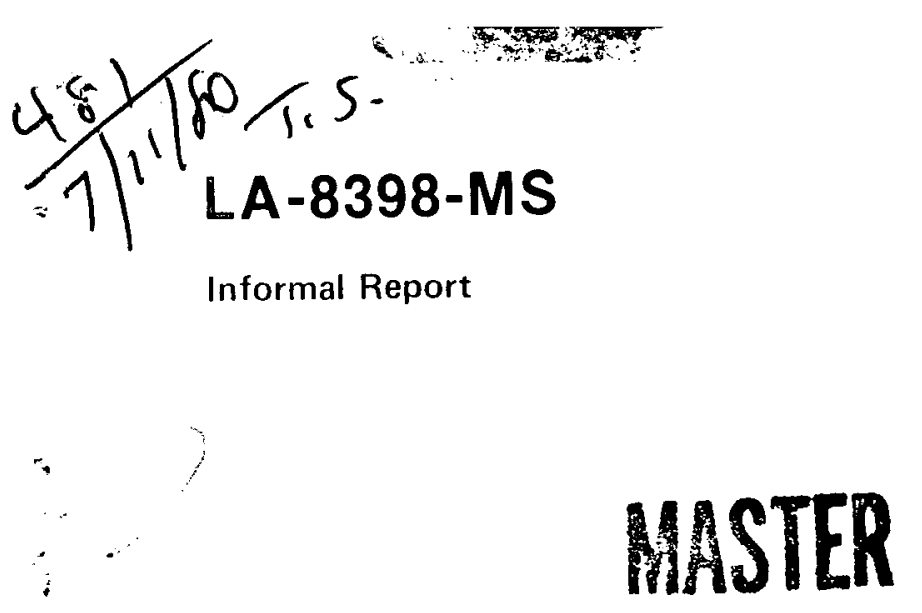

Preliminary Study of the Potential Environmental Concerns Associated with Surface Waters and Geothermal Development of the Valles Caldera 


\section{DISCLAIMER}

This report was prepared as an account of work sponsored by an agency of the United States Government. Neither the United States Government nor any agency Thereof, nor any of their employees, makes any warranty, express or implied, or assumes any legal liability or responsibility for the accuracy, completeness, or usefulness of any information, apparatus, product, or process disclosed, or represents that its use would not infringe privately owned rights. Reference herein to any specific commercial product, process, or service by trade name, trademark, manufacturer, or otherwise does not necessarily constitute or imply its endorsement, recommendation, or favoring by the United States Government or any agency thereof. The views and opinions of authors expressed herein do not necessarily state or reflect those of the United States Government or any agency thereof. 


\section{DISCLAIMER}

Portions of this document may be illegible in electronic image products. Images are produced from the best available original document. 
An Affirmative Action/Equal Opportunity Employer

This report was not edited by the Technical Information staff.

This repont was prepared as an account of work sponsored by the United States Government. Neither the United States nor the United States Department of Energy, nor any of their employees, makes any warranty, express or implied, of assumes any legal liability or responsibility for the accuracy, completeness, or usefulness of any information, apparatus, product, or process disclosed, or represents that its use would not infringe privately owned rights. Reference herein to any specific commercial product,

process, or service by trade name, mark, manufacturer, or otherwise, does not necessarily constitute or imply its endorsement, recommendation, or favoring by the United States Government or any agency thereof. The views and opinions of authors expressed herein do not necessarily state or reflect those of the United States Government or any agency thereof.

\section{UNITED STATES}

DEPARTMENT OF ENEROY

CONTRACT W-TAOE-TNO. Ie 


\title{
Preliminary Study of the Potential Environmental Concerns Associated with Surface Waters and Geothermal Development of the Valles Caldera
}

\author{
G. J. Langhorst
}
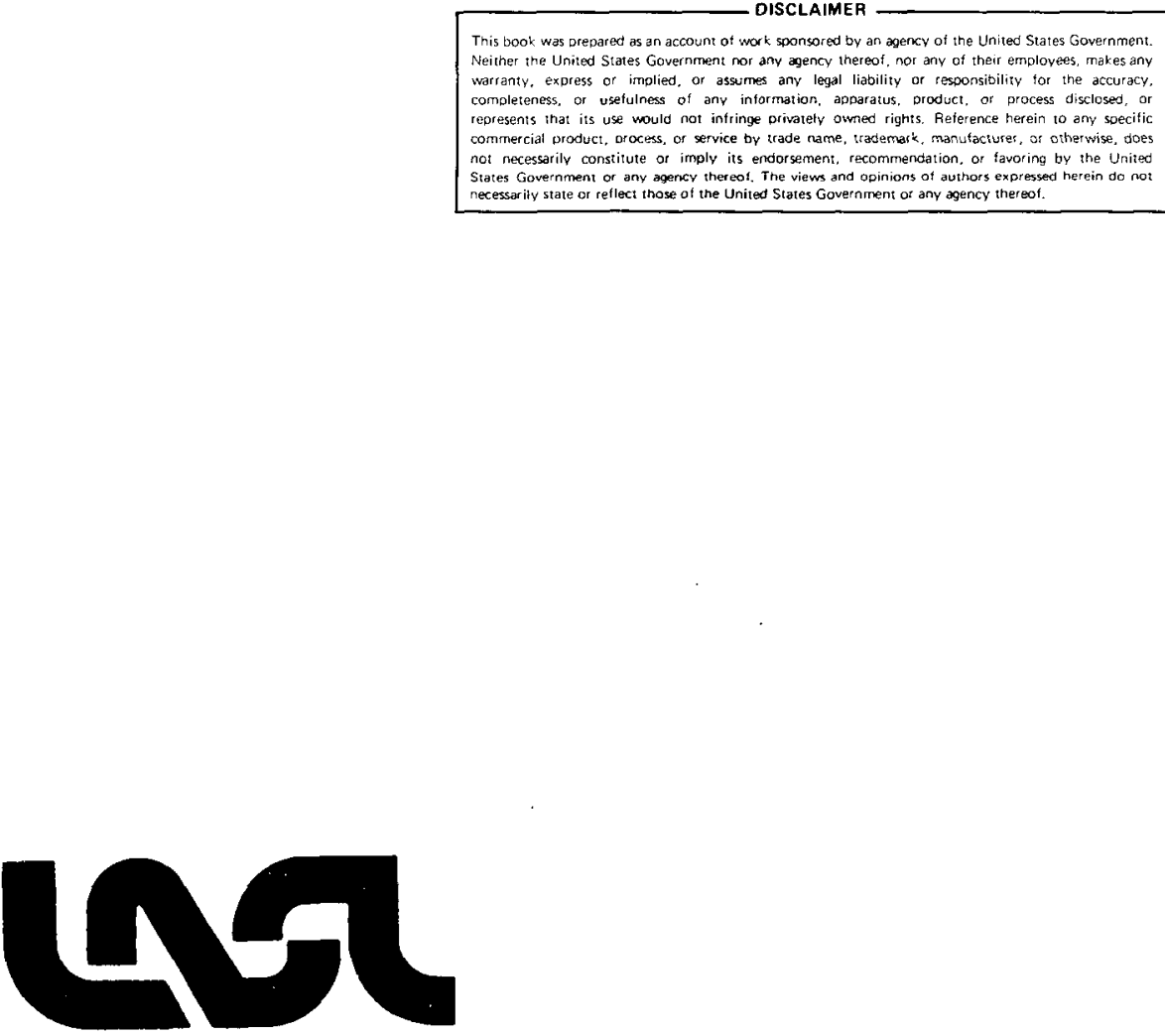


\title{
PRELIMINARY STUDY OF THE POTENTIAL ENVIRONMENTAL CONCERNS ASSOCIATED WITH SURFACE WATERS AND GEOTHERMAL DEVELOPMENT OF THE VALLES CALDERA
}

by

\author{
G. J. Langhorst
}

\begin{abstract}
This report is a preliminary evaluation of possible and probable problems that may be associated with hydrothermal development of the Valles Caldera Known Geothermal Resource Area (KGRA), with specific reference to surface waters. Beca use of the history of geothermal development and its associated environmental impacts, this preliminary evaluation indicates the Valles Caldera KGRA will be subject to these concerns. Although the exact nature and size of any problem that may occur is not predictable, the baseline data accumulated so far have delineated existing conditions in the streams of the Valles Caldera KGRA. Continued monitoring will be necessary with the development of geothermal resources. Further studies are also needed to establish guidelines for geothermal effluents and emissions.
\end{abstract}

\section{INTRODUCTION}

Geothermal power is not a new concept. In Larderello, Italy, the first major geothermal power plant was developed in 1904, and, in the 1950s, geothermal power was being developed in New Zealand. Japan, Mexico, and the USSR have since used geothermal resources as a source of power. In 1960, the Geysers in California became the site of the first commercial geothermal power plant in the United States.

Geothermal fields are currently classified as (1) dry steam, (2) hot water, and (3) hot dry rock reservoirs. The hot water fields are further subdivided into wet steam and low temperature reservoirs.

Dry steam fields produce steam that may be used directly to run turbines. The Geysers and Larderello, Italy are examples of dry steam fields currently being exploited. These resources are easy to use; however, the occurrences of dry steam fields are rare.
A more abundant resource is the low temperature hot water fields, which produce water at points below boiling. These are typified by hot mineral and thermal springs, many of which have been used for years for various purposes. Several of those low temperature reservoirs are currently being used for small scale power generation. Few pollution problems exist with these systems.

Hot water fields, with temperatures above the boiling point; but not high enough to produce usable steam, occur in large areas of the world. Large fields are found in California and in the Valles Caldera KGRA in north central New Mexico. In these fields, approximately $20 \%$ of the fluid is converted to steam to run turbines, while the remaining $80 \%$ is liquid waste.

The most abundant geothermal resource in the world is hot dry rock. These reservoirs yield no steam or hot water because the rock is essentially 
impermeable to water or because ground water circulation doesn't reach it. The Los Alamos Scientific Laboratory (LASL) has recently developed the first energy extracting system using hot dry rock.

Although there are different types of geothermal resources, their development is accomplished by operational phases that remain somewhat constant, and each phase has its concomitant environmental impacts. The production of geothermal power will entail (1) exploration, (2) test drilling, (3) production testing, (4) field development, (5) powerplant/powerline construction, and (6) full scale operations. The following discussion outlines, in general, these activities.

\section{A. Exploration}

$\therefore$

Geothermal resource exploration may be carried out by aerial surveillance or surface exploration. Both methods are used to determine primary characteristics of a proposed geothermal area. Some of the activities and parameters looked at are (1) shallow drilling to determine thermal gradients, (2) mapping, (3) seismic surveys, and (4) environmental surveys. If this phase indicates a productive resource, the next phase is initiated.

\section{B. Test Drilling}

Test drilling gives the developer more in depth data. These data are used to locate potentially productive zones, delineate the reservoir limits, and aid in determining the properties of the reservoir and reservoir fluids. Heavy equipment and drilling rigs are used in this phase.

\section{Production Testing}

After test drilling operations have successfully established a well in a potentially productive geothermal zone, the well is production tested. This testing will delineate such properties as (1) flow, (2) recharge potential, (3) composition and temperature of geothermal fluids and gases, (4) pressure and other physical properties, and (5) maximum production expected from the well.

\section{Field Development}

When test drilling and production testing activities warrant, field development operations are started. This involves the drilling of additional wells and further construction activities. Environmental impacts associated with field deveopment will be similar to those from other phases, but amplified because of increased activity.

\section{E. Powerplant and Powerline Construction}

The. construction of powerplant and powerline facilities is similar to that of conventional facilities. A central powerplant, fed by several geothermal wells, converts the superhot water and/or steam to electrical energy. A powerline corridor is necessary to transmit the electricity.

\section{F. Full Scale Operation}

Geothermal fields will probably not be developed unless they show commercial potential for at least 30 y.

\section{PROBLEM DEFINITION AND JUSTIFICATION}

The necessity of evaluating environmental concerns regarding geothermal development arises from the National Environmental Policy Act (NEPA) of 1969, implemented by Executive Order 11514, and the Council on Environmental Quality Guidelines of August 1, 1973 (38 PR 20550). Anything that will affect the quality of the human environment must have an environmental statement submitted for legislation or other appropriate federal action. Geothermal technology development is maintained under the Department of Energy (DOE) Division of Geothermal Energy (DGE). This agency was given guidelines for the preparation of an environmental statement (ERHQ-0001, Guidelines to the Preparation of Environmental Reports for Geothermal Development Projects, February 1977). ${ }^{2}$ DGE guidelines require an environmental report for all phases of geothermal development.

Specific issues include land disturbances, atmospheric emissions, and aquatic emissions. This report examines these issues in relation to the surface water environment of the Valles Caldera. Major pathways to the surface waters are identified, and suggestions for mitigating impacts offered.

Union Oil Company, Public Service Company of New Mexico, and DOE have announced that they plan to construct a $50 \mathrm{MWe}$ liquid-dominated 
hydrothermal power plant in the Valles Caldera. Electricity generated from this plant will be transmitted to points of distribution, which are speculated to be Los Alamos, Española, Santa Fe, Cuba, or Albuquerque, New Mexico. ${ }^{3}$

This report will point out some of the potential environmental problems associated with geothermal resource development of the Valles Caldera, and serve as a vehicle for further environmental studies in the event of full field development.

\section{ISSUES AFFECTING THE VALLES CALDERA}

During development of geothermal resources, site alterations and their concomitant effects upon the environment will occur. The amount and extent of these effects will depend on the environmental setting, size of the planned facility, pre-planning of development, construction practices, and site restoration. In this regard the environmental issues of concern are land disturbances, atmospheric emissions, and aquatic emissions.

\section{A. Land Disturbances}

Land disturbances will not be specific to any particular activity; however, they may be more prevalent in some phases of development than in others. In test drilling, production testing, field development, and powerplant/powerline construction, considerable land alteration will occur. These activities will require road building, pipelines and other facilities, and clearing for parking lots and storage areas. Because of the steep terrain of the Valles Caldera KGRA, substantial modification of the land is likely to occur. Soil erosion may become a serious problem unless construction activities are handled effectively. Thus, extra care will have to be taken to minimize such factors as oversteepening of cut-and-fill slopes, loss of vegetative cover, and an increased concentration of runoff on natural slopes. In full scale operation, only minimal additional excavation should be necessary.

Soil erosion will cause an increase in stream siltation and the suspended sediment load. Increases in the suspended sediment load can adversely affect aquatic life by reducing the oxygen supply, reducing light penetration, and affecting water temperatures; sediments may invade sensitive spawning areas of unique and endangered species, such as the Jemez Mountain Salamander (Plethodon neomexicanus), found in the Rio Cebolla. Because of leached nutrients carried into surface water, algal blooms may also occur, further depleting the dissolved oxygen supply.

The most effective means of reducing damage to the surface water environment (caused by land disturbances) is through proper planning and management practices. Reseeding of disturbed land surfaces will reduce erosion and aerial photographs can be used to show the most advantageous places for roads. With proper planning and construction, one road may serve many sites. In addition, proper tim. ing of construction activities can prevent interference with spawning habits of aquatic life near proposed site areas.

Weather is also an important consideration. Heavy excavation activities should be avoided during times of increased precipitation. The Jemez Plateau usually receives 35 to $36 \mathrm{~cm}$ of precipitation per year. ${ }^{3}$ During 1976 and 1977 , more than $50 \%$ of the rainfall occurred during July, August, and September (Fig. 1).

\section{B. Atmospheric Emissions}

Most of the atmospheric emissions of a geothermal power plant occur as part of the natural composition of the atmosphere and at levels that are not normally toxic. However, there are some constituents of concern from both a toxic and environmental point of view. Table I shows ranges of gases in geothermal vapors in concentration per volume per cent. In This table, $\mathrm{H}_{2} \mathrm{~S}$ appears to pose the greatest potential pollution problem.

After treatment by current abatement procedures, $\mathrm{H}_{2} \mathrm{~S}$ released to the atmosphere should be diluted, during periods of normal atmospheric mixing, to such an extent that it would be of no particular concern. However, during an inversion or stagnant air conditions, $\mathrm{H}_{2} \mathrm{~S}$ could then have an effect on the surface water environment via rainfall transport to the ground and surface waters. Both $\mathrm{H}_{2} \mathrm{~S}$ and sulfur dioxide could be converted to elemental surfur or sulfate acids, which would then be reflected by changes in the $\mathrm{pH}$ and odor of the waters. ${ }^{8}$ 


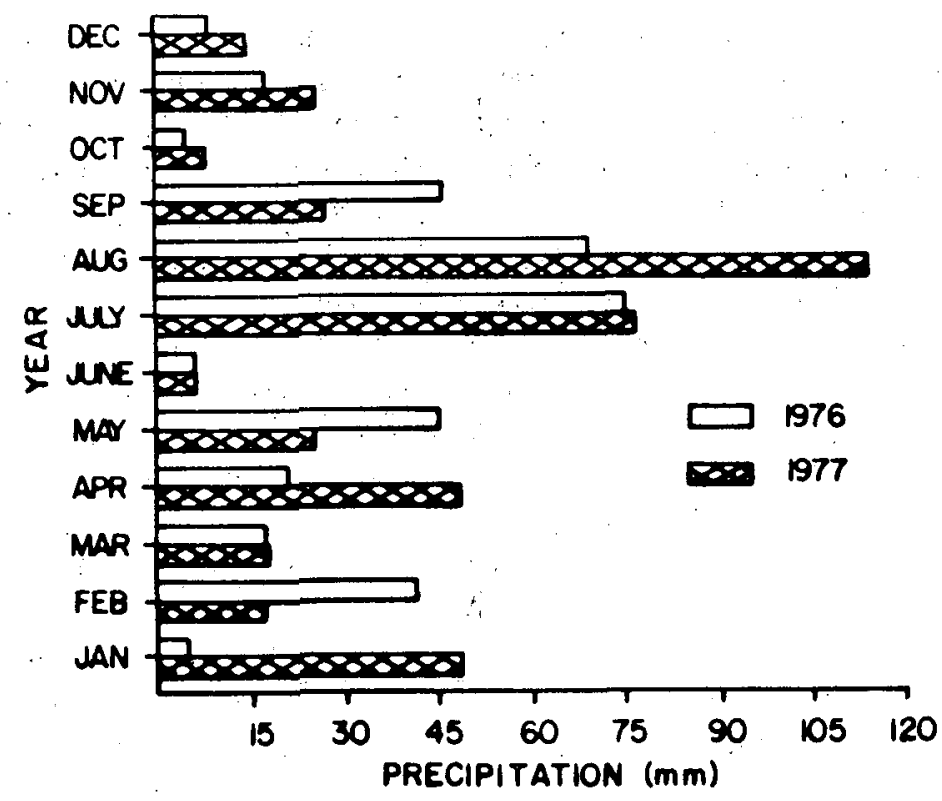

Fig. 1.

Precipitation at Fenton Hill, 1976 and 1977.

TABLE I

\section{GAS COMPOSITION OF GOETHERMAL VAPORS}

\begin{tabular}{l}
\multicolumn{1}{c}{ Constituent } \\
\hline Ammonia \\
Argon \\
Arsenic \\
Boric Acid \\
Carbon Dioxide \\
Carbon Monoxide \\
Helium \\
Hydrocarbon \\
( $\mathrm{C}_{2}$ and greater) \\
Hydrogen \\
Hydrogen Fluoride \\
Hydrogen Sulfide \\
( $\mathrm{H}_{2}+\mathrm{H}_{2} \mathrm{~S}$ ) \\
Mercury \\
Methane \\
Nitrogen \\
( $\mathrm{N}_{2}+$ Ar) \\
Oxygen \\
Sulfide Oxides
\end{tabular}

\section{Concentration \\ (vol\%)}

$0-5.36$
$0-6.3$
$0.002-0.05$
$0-0.45$
$0-99$
$0-3$
$0-0.3$
$0-18.3$
$0-39$
0.00002
$0-42$
$0.2-6$
$0.007-40.7(\mathrm{ppb})$
$0-99.8$
$0-97.1$
$0.6-96.2$
$0-64$
$0-31$

Mercury has been reported at varying concentrations from different geothermal fields. Reported concentrations range from 200 to 50000 parts per billion. Gaseous mercury can be transformed by rainfall into particulate form through reduction or adhesion on inorganic surfaces, or by combining with organics. ${ }^{7}$ In the particulate form, mercury can then be introduced into the watershed and, subsequently, accumulate in the food chain.

Radium is usually found in geothermal systems, and, if present in sufficient quantities, tends to precipitate out in well piping and machinery.? Radon, a gaseous product of radium decay, has a half life of 3.82 days and is an alpha emitter. If inversion conditions occurred for an extended period of time, radon and its decay products $\left({ }^{210} \mathrm{~Pb}\right.$, etc) could become an environmental problem by wet or dry deposition to ground and surface waters.

A major mechanism for a large release of geothermal pollutants is a blowout. A blowout is a sudden escaping of steam and perhaps hot water from a geothermal well. This may be caused by either ruptures of casing and wellhead equipment or improper drilling procedures. Adverse impacts can result from direct discharges of geothermal fluids to surface waters, or indirect effects when the atmospheric emissions are returned to the ground by rainfall or settling. In California, a blowout occurred at the 
Geysers in 1957. Because it could not be capped, this blowout emitted, by 1972, more than 8164800 metric tons of steam, 4536 metric tons of ammonia, 5443 metric tons of methane, and 3629 metric tons of hydrogen sulfide.

Blowout prevention is accomplished by (1) proper site selection, (2) use of appropriate casing material, and (3) correct drilling procedures. Planning for equipment and training of personnel in the event of a blowout, coupled with a thorough cleanup operation afterwards, can lessen the impact to the surface water environment. ${ }^{5}$

There are several contemporary processes available for the control of air pollution from geothermal operations. Hydrogen sulfide is the atmospheric pollutant of greatest concern. At the Geysers geothermal power plant in California, Pacific Gas and Electric Company has used a new treatment system, the Stretford process, for removal of $\mathrm{H}_{2} \mathrm{~S}$. Basically this process removed $\mathrm{H}_{2} \mathrm{~S}$ by scrubbing the gas stream after it leaves the condensor ejector and before it reaches the cooling tower. Elemental sulfur is produced after a series of reactions in the scrubbing process. Applied to the geothermal systems at the Geysers, an 80 to $90 \%$ removal of $\mathrm{H}_{2} \mathrm{~S}$ has been achieved. The remaining 10 to $20 \%$ is apparently released to the atmosphere.

A more recent $\mathrm{H}_{2} \mathrm{~S}$ abatement technique, developed by the EIC Corporation (EIC process), removes the $\mathrm{H}_{2} \mathrm{~S}$ from the incoming steam before it reaches the turbines. This method is valuable because it can help to reduce the corrosive properties of the steam. In field tests at the Geysers, a $97 \% \mathrm{H}_{2} \mathrm{~S}$ removal efficiency has been achieved, along with about $80 \%$ removal of ammonia and boric acid. ${ }^{6}$ However, some factors, such as operating costs, make the EIC process less desirable at this point than the Stretford process.

\section{Aquatic Emissions}

During geothermal power production, pollution of surface water by liquid or condensate emissions is likely. In the producing geothermal field several points exist where accidental or planned emissions may occur. Some of these emission points are at the

1. well head during initial or periodic full flow venting,

2. separator during liquid phase wasting,
3. condenser during condensate discharge,

4. cooling tower during heat reduction,

5. fluid treatment system during waste water treatment or sludge removal, and

6. at the reinjection well during fluid reinjection.

The number and types of occurrences will depend on the type of system employed, character of the fluid, and whether reinjection is possible. The Redondo Creek area of the Valles Caldera KGRA is the site for Union Oil's proposed power plant. Disposal of the brine will probably be by reinjection, with limited or no surface disposal.

Two types of geothermal power generation systems are shown in Figs. 2 and 3. Figure 2 shows a liquid dominated flash steam turbine system in which the spent fluids and gases are discharged directly to the surface or atmosphere. From an environmental point of view this is the most undesirable of the two systems. Figure 3 shows the same type of power conversion cycle, but with all remaining wastes being reinjected into the ground or lost to the atmosphere from the cooling tower as drift or evaporation. The actual system to be used in the Valles Caldera will probably be much like the system in Fig. $3 .^{8}$

Aquatic emissions from geothermal sources pollute surface water environments in two ways-ther$\mathrm{mal}$ and/or chemical. Because of the low efficiency of heat to power conversion (current conversion efficiencies are on the order of about $20 \%),{ }^{6}$ waste heat can be a substantial problem. The use of external cooling water in the Valles Caldera is not possible because of the limited surface water resource. With the use of cooling towers and with recycling of cooling water, most of the heat will be dissipated to the atmosphere. However, if cooling water is discharged into the streams, or if the geothermal fluid itself is released directly into the streams, intense thermal pollution would occur. The extent of this effect would depend on the amount and duration of the fluid released.

Short term temperature increases would cause temperature sensitive species to move out of the thermally affected areas. After the thermal effects have subsided, these species could be expected to return. In the Valles Calders, trout would probably be the aquatic organism most affected.$^{9}$ 


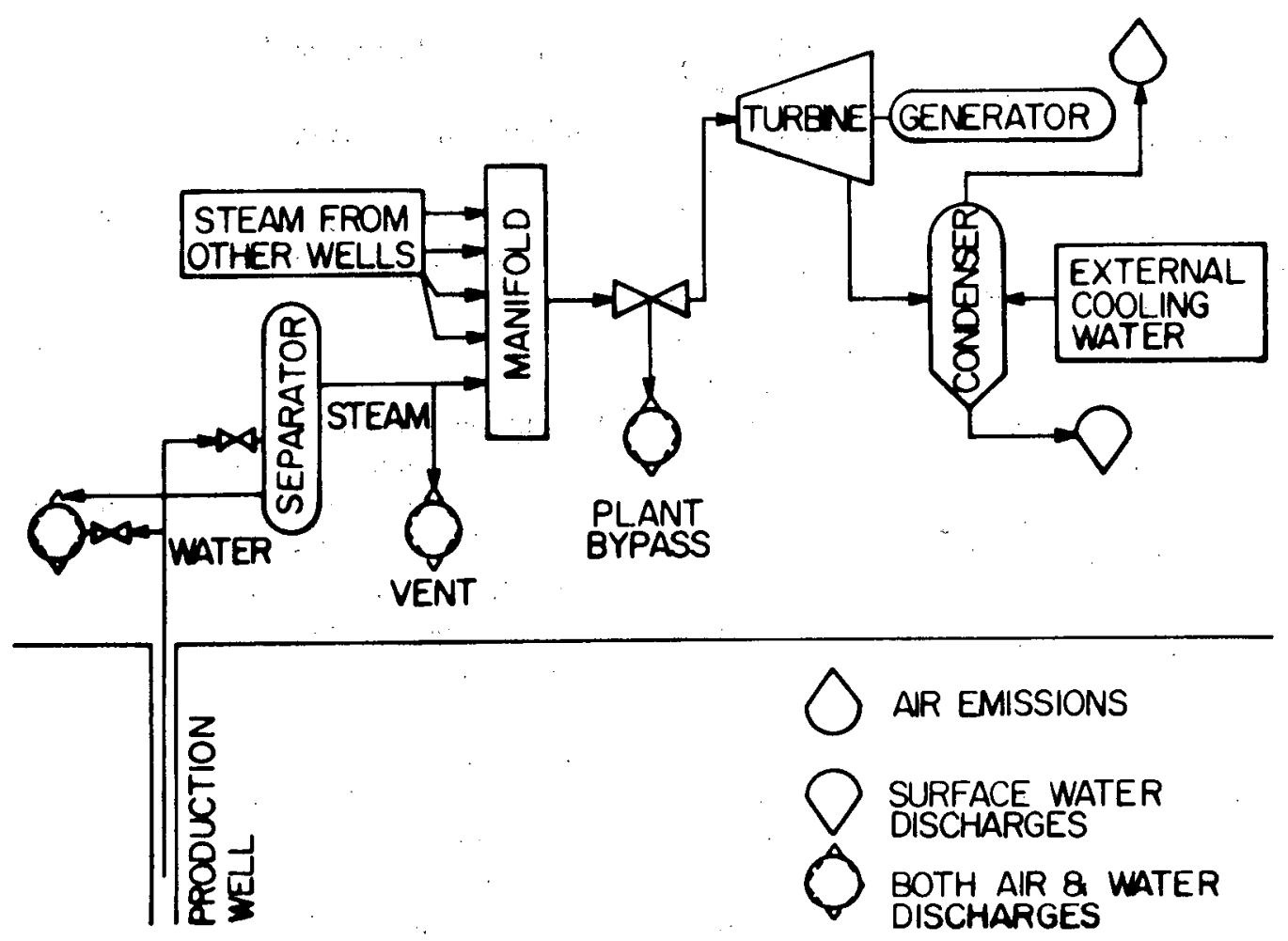

Fig. 2.

Schematic of a geothermal power plant with direct discharges to the environment.

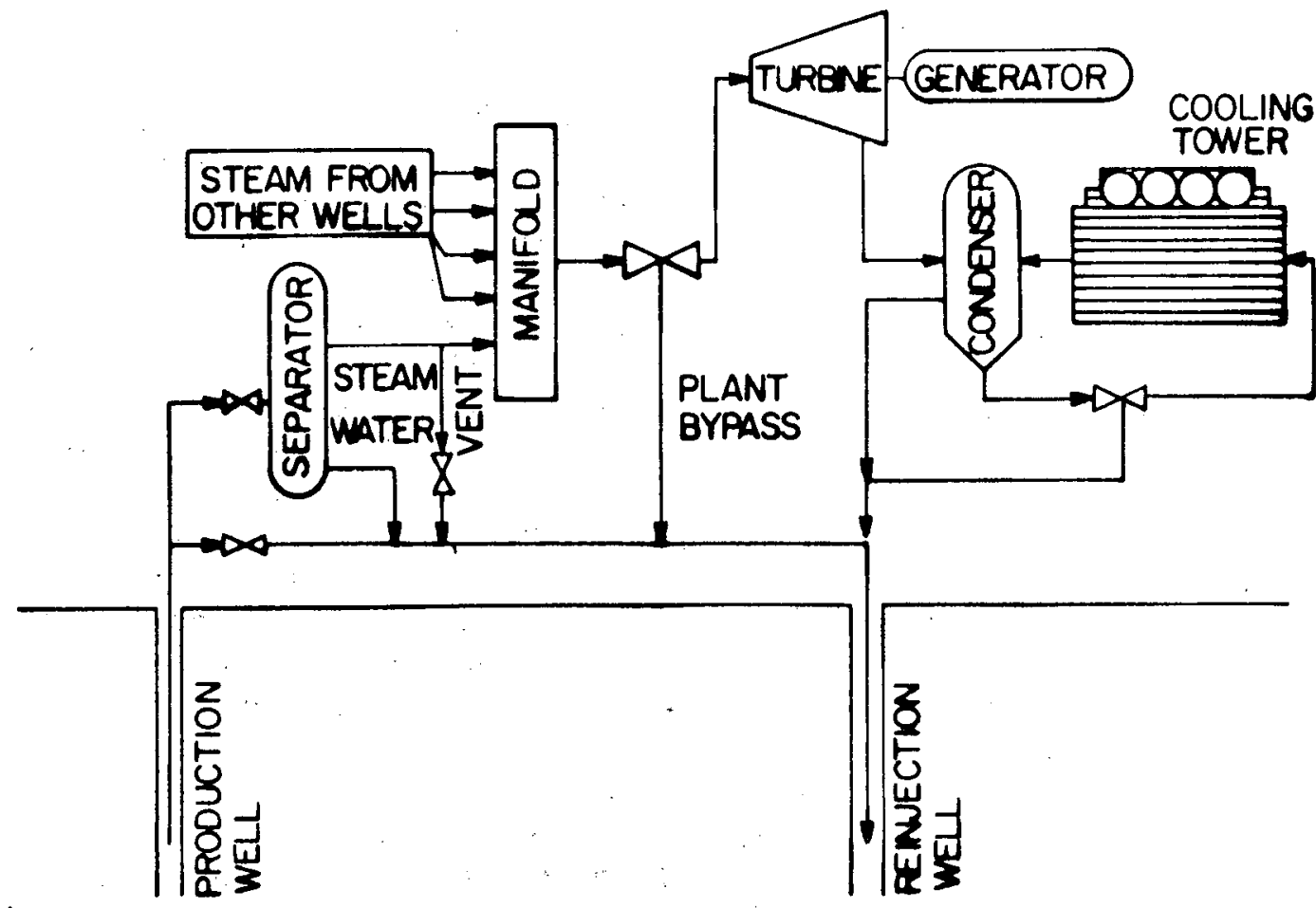

Fig. 3.

Schematic of a geothermal power plant with reinjection of wastes. 
A long term thermal input would cause a decrease in both biomass and numbers of the nontolerant species, with a corresponding increase in biomass and numbers of thermally tolerant species. However, changes in the aquatic insect population, caused by thermal fluctuaction, may be genetic rather than physiological. ${ }^{10}$

Even though the exact chemical composition of the brine in the Valles Caldera KGRA has not been reported, other studies (Cushman, R.M., et al, 1977) have shown, by comparing other geothermal fields, that there are some general constituents that should be of concern. That study ${ }^{11}$ found $\mathrm{Fe}, \mathrm{Pb}$, and $\mathrm{Zn}$ had high potentials for toxic effects on aquatic organisms and that $\mathrm{Fe}, \mathrm{Mn}, \mathrm{Pb}$, and $\mathrm{Zn}$ had high hazard potentials to aquatic organisms by bioaccumulation. In Big Sulfur Creek in the Geysers geothermal area in California, boron, as boric acid, was identified as the toxin possibly responsible for a steelhead trout kill. "All geothermal fluids have $\mathrm{Na}$, $\mathrm{Cl}, \mathrm{Ca}, \mathrm{K}, \mathrm{Mg}, \mathrm{HCO}_{3}, \mathrm{SO}_{4}$, and $\mathrm{SiO}_{4}$ in varying concentrations. Many hot water fields average between 2000 and 20000 ppm TDS. Dissolved gases may include $\mathrm{O}_{2}, \mathrm{CO}_{2}, \mathrm{H}_{2} \mathrm{~S}, \mathrm{CH}_{4}, \mathrm{H}_{2}, \mathrm{NH}_{3}$, and $\mathrm{N}_{2}$ Actual concentrations of any of these constituents will be site specific and may even vary from well to well, and, from time to time, within a well.

The greatest problem in liquid dominated geothermal systems may be disposal of the massive amounts of waste water. In the Valles Caldera, a proposed system of $50 \mathrm{MWe}$ would normally consume 34 to $68 \mathrm{~kg} / \mathrm{kwhr}$. This translates to 16 to $32 \times$ $10^{6} \mathrm{~m}^{3} / \mathrm{y}$ ( 13000 to 26000 acre feet) of water. Because $88 \%$ of this fluid must be disposed of, it is logical to assume that disposal will be by reinjection. Proper casing of reinjection wells is necessary to prevent indirect contamination of surface waters by ground waters.

If there are to be any discharges to streams, special procedures are called for. Holding ponds will be necessary to cool waste waters, and chemical treatment will be necessary to mitigate harmful chemical constituents.

\section{BASELINE DATA}

Nine major drainage systems are found within the Valles Caldera KGRA. These perennial streams are Rio de Las Vacas, Rio Cebolla, Rio Guadalupe, Jemez River, East fork of the Jemez River, Redondo
Creek, Sulfur Creek, San Antonio Creek, and Vallecitos Creek. Vallecitos Creek will not be considered in this report because it does not drain areas currently considered for geothermal development. The other eight streams drain areas of potential contamination in the immediate and near future. Figure 4 shows the area being considered in this report, along with the eight streams.

Four years of data from the sampling stations located on these streams have been accumulated by LASL's Environmental Surveillance Group (H-8). ${ }^{12-}$ is $\mathrm{A}$ baseline information table has been compiled from these data (Table II). Table II shows mean values and confidence intervals $(\alpha=0.05)$ for the measured parameters. Because of conditions resulting from seasonal variations, some sample values are expected to fall outside the indicated range. However, when two or three consecutive samples fall outside the expected distribution, investigative procedures should be initiated to determine the cause of the variance and whether it can be attributed to geothermal activities.

The New Mexico Water Quality Standards (October 1976) ${ }^{16}$ list designated uses of surface water in the Valles Caldera KGRA and set standards for those waters. The recognized uses of surface waters in the area include domestic water supplies, fish cultures, high quality cold water fisheries, irrigation, livestock and wildlife watering, and secondary contact recreation.

A comparison of Table II with the New Mexico Water Quality Standards for Interstate and Intrastate Streams shows that the only parameters with mean values in excess of the standards are $\mathrm{pH}$ at sampling station $\mathrm{V}$ and specific conductance at sampling stations R, V, and S (Fig. 4). Sampling station V is located on Sulfur Creek above its confluence with Redondo Creek. Sulfur Creek drains a small basin that contains thermal springs (the most important is Sulfur Hot Springs), which contributes to the base flow of the creek. The high specific conductivity and low $\mathrm{pH}$ of Sulfur Creek is attributed to these springs. ${ }^{17}$

Sampling station $S$ is located above the confluence of the Rio Guadalupe with the Jemez River, and sampling station $R$ is located below that confluence. The high specific conductivity at these locations is caused by highly mineralized water from thermal springs, which flow into the Jemez River 


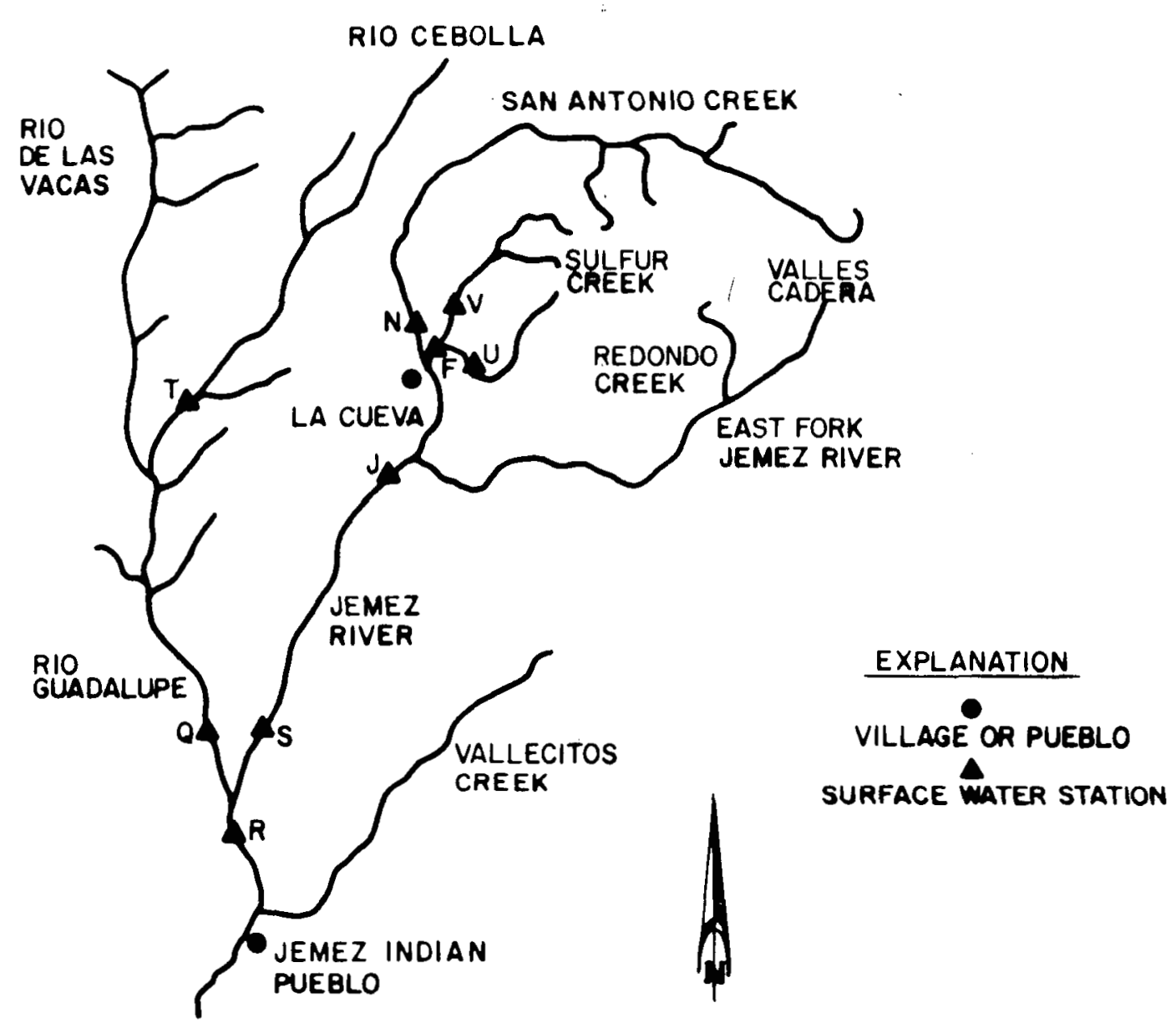

Fig. 4.

Major drainage systems within the Valles Caldera KGRA.

above these stations. The thermal springs at Soda Dam are the main contributors. ${ }^{17}$

Given these naturally-occurring sources of variance from the water quality standards, it seems reasonable that those standards for the parameters of $\mathrm{pH}$ and specific conductance for the given reaches of the Jemez River and Sulfur Creek should be revised accordingly.

\section{MONITORING}

Monitoring surface water quality is necessary, even if there are to be no planned surface water discharges. The reasons for this are accidental discharge of fluids by broken or leaking pipes, escape of fluids from reinjection wells into aquifers and springs, leakage or seepage of holding ponds or sumps, and/or possible contamination of surface water by air emissions as "fallout." Water quality monitoring is recommended for the same constituents and properties for which the geothermal effluent itself is monitored.

The monitoring scheme should be simple but thorough. Samples should be taken at three points-one upstream from the effluent or point of discharge, one at the effluent or point of discharge, and one far enough downstream from the effluent or point of discharge to allow for mixing. Sampling frequency should reflect the variability of effluent characteristics and of stream flow.

The Environmental Protection Agency's Office of $\therefore$ Water and Hazardous Materials has developed criteria for various constituents in geothermal fluids in relation to aquatic life and agricultural uses. These criteria are shown in Tables III and IV. Many of the known chemical constituents of geothermal fluids have not been considered. Boron, arsenic, and 
TABLE II

SURFACE WATER QUALITY

\begin{tabular}{l}
\multicolumn{1}{c}{\begin{tabular}{c}
\multicolumn{1}{c}{ Chemical } \\
Analyses
\end{tabular}} \\
\hline Silica $(\mathrm{mg} / \mathrm{l})$ \\
Calcium \\
Magnesium \\
Sodium \\
Carbonate \\
Bicarbonate \\
Sulfate \\
Chloride \\
Fluoride \\
Nitrate \\
TDS \\
Total Hardness \\
(as CaCOs) \\
Specific Cond \\
( $\mu$ mho/cm) \\
pH \\
Temperature $\left({ }^{\circ} \mathrm{C}\right)$ \\
Discharge \\
Estimate $(\ell / \mathrm{s})$
\end{tabular}

\begin{tabular}{|c|c|}
\hline Station $\mathbf{R}$ & Station $T$ \\
\hline $42.13 \pm 28.42^{\mathrm{a}}$ & $35.82 \pm 8.04$ \\
\hline $43.65 \pm 19.10$ & $19.00 \pm 4.82$ \\
\hline $5.18 \pm 3.82$ & $2.45 \pm 2.08$ \\
\hline $93.84 \pm 283.28$ & $11.27 \pm 3.70$ \\
\hline $1.89 \pm 9.38$ & $0.91 \pm 6.04$ \\
\hline $164.76 \pm 92.66$ & $77.64 \pm 22.62$ \\
\hline $14.41 \pm 8.24$ & $3.14 \pm 5.10$ \\
\hline $92.65 \pm 90.10$ & $3.18 \pm 4.36$ \\
\hline $0.89 \pm 0.70$ & $0.46 \pm 0.32$ \\
\hline $0.19 \pm 0.26$ & $0.15 \pm 0.24$ \\
\hline $426.94 \pm 239.96$ & $137.27 \pm 47.68$ \\
\hline $129.29 \pm 57.32$ & $58.64 \pm 14.76$ \\
\hline $625.00 \pm 475.08$ & $167.27 \pm 46.76$ \\
\hline $8.06 \pm 0.60$ & $7.79 \pm 0.80$ \\
\hline $10.69 \pm 13.48$ & $10.09 \pm 11.18$ \\
\hline $584.00 \pm 641.40$ & $78.50 \pm 112.56$ \\
\hline
\end{tabular}

\begin{aligned} & Station U \\ & \hline 29.67 \pm 8.78 \\ & 30.22 \pm 8.64 \\ & 3.44 \pm 3.18 \\ & 17.44 \pm 18.96 \\ & 0 \pm 0 \\ & 37.33 \pm 14.56 \\ & 9.71 \pm 13.76 \\ & 42.11 \pm 49.42 \\ & 0.28 \pm 0.64 \\ & 0.19 \pm 0.26 \\ & 196.33 \pm 123.42 \\ & 69.11 \pm 31.46 \\ & 245.56 \pm 180.94 \\ & 7.52 \pm 0.58 \\ & 4.22 \pm 10.58 \\ & 15.75 \pm 19.30\end{aligned}

\begin{aligned} Station V \\ \hline \\ $42.22 \pm 8.82 \\ 72.89 \pm 47.34 \\ 11.22 \pm 6.70 \\ 23.11 \pm 15.02 \\ 0 \pm 0 \\ 0 \pm 0 \\ 267 \pm 210.18 \\ 7.89 \pm 10.92 \\ 0.42 \pm 0.38 \\ 0.23 \pm 0.26 \\ 537.67 \pm 343.16 \\ 133.75 \pm 194.88 \\ 722.78 \pm 525.96 \\ 3.82 \pm 0.90 \\ 4.89 \pm 7.52 \\ 18.38 \pm 34.36\end{aligned}$
Station F
$33.58 \pm 5.94$
$41.58 \pm 17.66$
$6.42 \pm 5.22$
$20.83 \pm 15.10$
$0 \pm 0$
$12.42 \pm 15.58$
$113.17 \pm 86.56$
$34.58 \pm 30.28$
$0.32 \pm 0.30$
$0.14 \pm 0.10$
$279.83 \pm 152.60$
$130.50 \pm 56.22$
$327.62 \pm 36.20$
$7.00 \pm 2.14$
$5.30 \pm 10.34$
$30.70 \pm 58.06$

\begin{tabular}{|c|c|c|c|c|}
\hline $\begin{array}{l}\text { Chemical } \\
\text { Analyses }\end{array}$ & Station $\boldsymbol{J}$ & Station $\mathbf{H}$ & Station Q & Station S \\
\hline Silica $(\mathrm{mg} / \ell)$ & $43.69 \pm 21.60$ & $50.46 \pm 19.36$ & $25.62 \pm 19.42$ & $49.92 \pm 21.40$ \\
\hline Calcium & $14.85 \pm 5.46$ & $15.92 \pm 5.50$ & $45.08 \pm 23.80$ & $43.50 \pm 23.34$ \\
\hline Magnesium & $3.23 \pm 2.18$ & $3.23 \pm 4.62$ & $6.31 \pm 4.58$ & $5.67 \pm 3.82$ \\
\hline Sodium & $16.00 \pm 11.10$ & $13.85 \pm 10.36$ & $14.38 \pm 9.88$ & $67.33 \pm 56.22$ \\
\hline Carbonate & $0 \pm 0$ & $0 \pm 0$ & $1.00 \pm 3.82$ & $2.40 \pm 8.58$ \\
\hline Bicarbonate & $65.86 \pm 34.70$ & $66.92 \pm 29.42$ & $152.54 \pm 90.48$ & $169.73 \pm 83.36$ \\
\hline Sulfate & $9.14 \pm 6.70$ & $8.21 \pm 5.88$ & $6.68 \pm 6.28$ & $18.83 \pm 35.86$ \\
\hline Chloride & $7.69 \pm 6.44$ & $3.85 \pm 3.98$ & $7.00 \pm 9.42$ & $84.67 \pm 86.64$ \\
\hline Fluoride & $0.68 \pm 0.52$ & $1.11 \pm-1.00$ & $0.57 \pm 0.58$ & $0.93 \pm 0.54$ \\
\hline Nitrate & $0.15 \pm 0.20$ & $0.17 \pm 0.12$ & $0.17 \pm 0.26$ & $0.29 \pm 1.28$ \\
\hline TDS & $160.08 \pm 62.00$ & $167.31 \pm 64.40$ & $219.92 \pm 158.16$ & $412.0 \pm 195.5$ \\
\hline $\begin{array}{l}\text { Total Hardness } \\
\text { (as } \mathrm{CaCO}_{3} \text { ) }\end{array}$ & $50.92 \pm 14.94$ & $52.85 \pm 24.64$ & $138.77 \pm 70.54$ & $137.53 \pm 54.32$ \\
\hline $\begin{array}{l}\text { Specific Cond } \\
(\mu \mathrm{mho} / \mathrm{cm})\end{array}$ & $167.32 \pm 58.40$ & $159.00 \pm 42.26$ & $308.08 \pm 176.42$ & $640.00 \pm 374.80$ \\
\hline $\mathrm{pH}$ & $7.75 \pm 0.62$ & $7.74 \pm 0.66$ & $7.98 \pm 0.52$ & $8.13 \pm 0.50$ \\
\hline Temperature $\left({ }^{\circ} \mathrm{C}\right)$ & $7.64 \pm 10.64$ & $6.73 \pm 11.04$ & $11.09 \pm 11.88$ & $11.36 \pm 10.92$ \\
\hline $\begin{array}{l}\text { Discharge } \\
\text { Estimate }(\ell / \mathrm{s})\end{array}$ & $328.50 \pm 321.18$ & $107.40 \pm 184.22$ & $119.50 \pm 336.54$ & $383.50 \pm 328.02$ \\
\hline
\end{tabular}

${ }^{a}$ Confidence value expressed as $\bar{x} t_{0.06} a_{2}$ 
TABLE III

\section{AGRICULTURAL USE CRITERIA FOR CONSTITUENTS IN GEOTHERMAL FLUIDS FROM "QUALITY CRITERIA FOR WATER"}

\section{Livestock \\ Watering}

Ammonia
Arsenic
Barium
Beryllium
Boron
Cadmium
Chromium
Copper
Iron
Lead
Manganese
Mercury
Nitrates
Phosphorus
Selenium
Silver
Hydrogen sulfide
Zinc

Ammonia

Barium

Beryllium

Boron

\section{$0.1 \mathrm{mg} / \mathrm{l}$}

0.001 to $0.500 \mathrm{mg} / \mathrm{l}$

\section{$0.75 \mathrm{mg} / \ell$}

Crop

Irrigation

Remarks

No criteria suggested

Tocixity to some crops at $0.5 \mathrm{mg} / \ell$

No criteria suggested

Crop toxicity acidity dependent;

no livestock criteria suggested

Toxic to sensitive plants, e.g., citrus at $<1 \mathrm{mg} / \ell$;

no livestock criteria suggested

Reduced crop yields at $1 \mathrm{mg} / \ell$;

crop accumulation related to zinc concentrations;

no livestock criteria suggested

No criteria suggested

Toxicity for plants begins at $0.1 \mathrm{mg} / \ell$;

no livestock criteria suggested

No criteria suggested

Toxic to plants at $<30 \mathrm{mg} / \mathrm{l}$;

no criteria suggested

$0.2 \mathrm{mg} / \ell$ suggested for acidiphilic

crops

Toxicity to plants increases with

decreasing $\mathrm{pH}$; no livestock criteria

suggested

Bioaccumulated but no criteria

suggested

No criteria suggested;

nutrient for crops

No criteria suggested;

nutrient for crops

No criteria suggested

No criteria suggested

No criteria suggested

Toxic to some crops at 0.4 to $25 \mathrm{mg} / \ell$;

may cause iron deficiency in plants;

no livestock criteria suggested

500 to 15000

$\mathrm{mg} /$ / suggested

Osmotic effects in plants;

variable harm to both

plants and animals

Toxic to certain plants;

ratio to other cations important;

no criteria given

-Environmental Protection Agency; Quality Criteria for Waster; Office of Water and Hazardous Materials; EPA-440/9-76-023;

July 1976. 
TABLE IV

AQUATIC LIFE CRITERIA FOR CONSTITUENTS IN
GEOTHERMAL FLUIDS FROM "QUALITY CRITERIA FOR WATER"

\begin{tabular}{|c|c|c|c|}
\hline $\begin{array}{l}\text { Criteria for } \\
\text { Constituent }\end{array}$ & $\begin{array}{l}\text { Criteria for } \\
\text { Fresh Water }\end{array}$ & Marine Water & Remarks \\
\hline $\begin{array}{l}\text { Ammonia } \\
\text { (un-ionized) }\end{array}$ & $0.02 \mathrm{mg} / \mathrm{l}$ & & Toxicity pH dependent \\
\hline Arsenic & & & Daphnia impaired by $4.3 \mathrm{mg} / \ell$ \\
\hline Barium & & Toxicity level $>50 \mathrm{mg} / \ell$ & \\
\hline Beryllium & $\begin{array}{l}0.11 \mathrm{mg} / \ell \text { (soft water) } \\
1.1 \mathrm{mg} / \ell \text { (hard water) }\end{array}$ & Toxicity hardness-dependent & \\
\hline Boron & & & Toxic to minnows at $19000 \mathrm{mg} / \mathrm{l}$ \\
\hline Cadmium & $\begin{array}{l}0.004 \text { to } 0.0004 \mathrm{mg} / \ell \text { (soft water) } \\
0.12 \text { to } 0.0012 \mathrm{mg} / \ell \text { (hard water) }\end{array}$ & $0.005 \mathrm{mg} / \ell$ & Toxic at $<0.5 \mathrm{mg} / \ell$ all tests \\
\hline Chromium & $0.1 \mathrm{mg} / \ell$ & & $\begin{array}{l}\text { Toxicity varies with } \mathrm{pH} \\
\text { and oxidation state }\end{array}$ \\
\hline Copper & $0.196 \mathrm{~h} \mathrm{LC}_{50}$ & $0.196 \mathrm{~h} \mathrm{LC}_{\mathrm{so}}$ & Toxicity alkalinity-dependent \\
\hline Iron & $1.0 \mathrm{mg} / \mathrm{l}$ & & Toxicity variable \\
\hline Lead & $0.0196 \mathrm{~h} \mathrm{LC}_{\text {so }}$ (soluble lead) & & Salmonids most sensitive fish \\
\hline Manganese & & $0.1 \mathrm{mg} / \ell$ & Not a problem in fresh water \\
\hline Mercury & $0.0005 \mathrm{mg} / \ell$ & $0.001 \mathrm{mg} / \mathrm{l}$ & $\begin{array}{l}\text { High bioaccumulation; } \\
\text { thus affects human food }\end{array}$ \\
\hline Nitrates & & & Toxicity to fish $>900 \mathrm{mg} / \boldsymbol{l}$ \\
\hline Phosphorus & & $0.001 \mathrm{mg} / \ell \mathrm{P}$ & Eutrophication factor \\
\hline Selenium & $0.0196 \mathrm{~h} \mathrm{LC}_{80}$ & $0.0196 \mathrm{~h} \mathrm{LC}_{s 0}$ & Toxic at $>2.5 \mathrm{mg} / \ell$ \\
\hline Silver & $0.0196 \mathrm{~h} \mathrm{LC}_{50}$ & $0.0196 \mathrm{~h} \mathrm{LC}_{50}$ & Toxicity dependent on compound \\
\hline Hydrogen sulfide & $0.0002 \mathrm{mg} / \ell$ & $0.0002 \mathrm{mg} / \ell$ & Toxic at very low levels \\
\hline Zinc & $0.0196 \mathrm{~h} \mathrm{LC}_{\mathrm{so}}$ & & $\begin{array}{l}\text { Toxicity dependent on temperature } \\
\text { Dissolved oxygen, hardness }\end{array}$ \\
\hline TDS & & & Osmotic effects variable \\
\hline
\end{tabular}

${ }^{a}$ Environmental Protection Agency, Quality Criteria for Water, Office of Water and Hazardous Materials, EPA-440/9-76-023, July 1976.

barium have been found in geothermal fluids in concentrations that are higher than those found in other waters. ${ }^{6}$ Ultimately, the toxic effect of the various constituents, whether from acute or chronic exposures, will be the guideline for establishing effluent or emission standards.

\section{SUMMARY AND CONCLUSIONS}

In Lake County, Sonoma County, and Imperial County, California, water pollution has resulted from the geothermal plants currently in operation. ${ }^{18}$ Water pollution is also likely to occur in the Valles Caldera KGRA (because of geothermal resource development). Pollution of the streams originates from three sources-land disturbances, atmospheric emissions, and liquid effluent emissions. The exact amounts and consequences of these pollutants are site specific.

Land disturbances can be mitigated by proper construction practices and adequate planning. Erosion from construction activities is typically the main cause of concern.

Atmospheric emissions from geothermal power plants contain several constituents of environmental concern. Of these concerns, hydrogen sulfide is the greatest because of relatively high concentrations in geothermal fluids, obnoxious odor, and toxicity at higher concentrations. Various other constituents, such as sulfur dioxide, boron, mercury, radium, and radon, may also be considered as potential environmental problems. 
Blowouts, a potential problem in any hydrothermal system, can be lessened by adequate construction of wells and proper training of personnel. In the event of a blowout, immediate and thorough clean up procedures can lessen the impact to the aquatic surface supply.

Liquid effluents can have a double impact-thermal and/or chemical. The extent of the impacts will be partially dependent on the type of power generation system used, character of the geothermal fluid, and the type of waste water disposal used. Because of the limited land area and massive quantities of spent fluids, reinjection is typically the major method of disposal. Holding ponds and waste water treatment are necessary before any surface disposal can occur.

Baseline data, accumulated from four years of sampling by LASL's Environmental Surveillance Group, has delineated the existing conditions of the streams in the Valles Caldera KGRA. Constant variations in any of the measured parameters should be looked at in relation to geothermal activities in the area.

Monitoring is necessary on streams at or near any geothermal development activity. Monitoring programs should reflect the variability of the geothermal effluent and the stream flow.

Further studies are required to establish guidelines for geothermal effluents and emissions. Some constituents such as boron, arsenic, and barium have no effluent or emission standards, even though they are sometimes found in relatively high concentrations in geothermal emissions.

\section{ACKNOWLEDGMENTS}

I would like to extend my gratitude to F. R. Miera, Jr., K. H. Rea, Consuelo Montoya, Maxine Lewis, W. D. Purtymun, T. K. Thompson, and D. W. Wilson.

\section{REFERENCES}

1. K. H. Rae, "Environmental Investigations Associated with the LASL Hot Dry Rock Geothermal Energy Development Project," Los Alamos Scientific Laboratory report LA-6972 (December 1971).
2. Energy Research and Development Administration, "Guidelines to the Preparation of Environmental Reports for Geothermal Development Projects," U.S. Energy Research and Development Administration Division of Geothermal Energy report ERHQ-0001 (February 1977).

3. U.S. Forest Service, "Geothermal Leading: Final Environmental Statement," USDA-FS-R3FES Adm 76-05, Albuquerque, New Mexico (January 1977).

4. J. P. Hubbard, M. C. Conway, H. Campbell, G. Schmitt, and M. D. Hatch, "Handbook of Species Endangered in New Mexico," New Mexico Department of Game and Fish, Santa Fe, New Mexico (1978).

5. U.S. Department of the Interior, "Geothermal Handbook," U.S. Fish and Wildlife Service Geothermal Project, NP-21172, prepared by Jones and Stokes Associated, Inc., Sacramento, California (June 1976).

6. R. P. Hartley, "Pollution Control Guidance for Geothermal Energy Development," Industrial Environmental Research Laboratory, Cincinnati, Ohio, EPA-600/7-78-101 (June 1978).

7. G. K. Billings, Chairman, "Environmental Aspects of Geothermal Power Production," A report of the Subcommittee on the Envronment, Governor's Energy Task Force Committee of Geothermal Energy, Santa Fe, New Mexico (June 1975).

8. Baca Project, Geothermal Demonstration Power Plant Project Description. Response by Union Oil and PNM to Program Opportunity Notice EG77-N-03-1717 (January 31, 1978).

9. T. D. Brock, "Environmental Effects of Thermal Discharges on Biota and Aquatic Ecosystems," Part II, presented at IAEA Conf. on Environmental Effects of Cooling Systems at Nuclear Power Plants, Oslo, IAEA-SM-187/9 (August 26-30, 1974). 
10. J. W. Gibbons and R. R. Sharitz, "Thermal Alteration of Aquatic Ecosystems," Amer. Scientist, Vol. 62, N6, p. 660 (1974).

11. R. M. Cushman, S. G. Hildebrand, and R. W. Brocksen, "Potential Impacts on Aquatic Ecosystems from the Release of Trace Elements in Geothermal Fluids," Oak Ridge National Laboratory report ORNL/TM-6057 (1977).

12. W. D. Purtymun, W. H. Adams, and J. W. Owens, "Water Quality in Vicinity of Fenton Hill Site, 1974," Los Alamos Scientific Laboratory report LA-6093 (December 1975).

13. W. D. Purtymun, W. H. Adams, A. K. Stoker, and F. G. West, "Water Quality in Vicinity of Fenton Hill Site, 1975," Los Alamos Scientific Laboratory report LA-6511-MS (September 1976).

14. W. D. Purtymun, W. H. Adams, and A. K. Stoker, "Water Quality in Vicinity of Fenton
Hill Site, 1976," Los Alamos Scientific Laboratory report LA-73073-MS (May 1978).

15. W. D. Purtymun, A. K. Stoker, W. H. Adams, and J. W. Owens, "Water Quality in the Vicinity of Fenton Hill Site, 1977," Los Alamos Scientific Laboratory report LA-7468-PR (September 1978).

16. Environmental Protection Agency, "Quality Criteria for Water," Office of Water and Hazardous Materials, EPA-44091-76-023 (July 1976).

17. W. D. Purtymun, F. G. West, and W. H. Adams, "Preliminary Study of the Quality of Water in the Drainage Area of the Jemez River and Rio Guadalupe," Los Alamos Scientific Laboratory report LA-5595-MS (April 1974).

18. P. Elliekson, S. Brewer, and K. Knight, "Balancing Energy and the Environment: The Case of Geothermal Development," U.S. Department of Energy report R-2274-DOE (June 1978). 